\title{
Agriculture Extension and Value Chain Support Services for Seed Sector Development in Nepal
}

\author{
Suroj Pokhrel \\ Government of Nepal, Kathmandu, Bagmati, Nepal.
}

How to cite this paper: Suroj Pokhrel. (2021) Agriculture Extension and Value Chain Support Services for Seed Sector Development in Nepal. International Journal of Food Science and Agriculture, 5(3), 555-566

DOI: 10.26855/ijfsa.2021.09.028

Received: August 10, 2021

Accepted: September 2, 2021

Published: September 26, 2021

*Corresponding author: Suroj Pokhrel, Government of Nepal, Kathmandu, Bagmati, Nepal.

Email: surojpokhrel@yahoo.com

\begin{abstract}
Seed sector has been growing slowly with insufficient infrastructures, extension and value chain support services in Nepal. An exploratory review of the literature followed by a number of consultative interactions with value chain actors $(\mathrm{N}=90)$ was made in 2019, aiming to find the strengths and weaknesses of agriculture extension and support services on seed sector development, specific to Chitwan, Dolakha and Rupandehi districts. Findings revealed that a set of seed legislations were enforced followed by pluralistic agriculture extension system, coupled with a number of seed production initiatives in these districts. A number of government, non-government, private and community organizations are involved in seed sector development, despite, the seed replacement rate was very low and the value chain actors are demanding a number of support services to overcome the associated problems. Major issues to be resolved were, the availability of quality inputs (77\%), strong research and extension back up (72\%), credit/subsidy support (66\%), reducing the price gap on seed retailing (62\%), commercialization and lowering cost of production (60\%), infrastructure development (55.6\%), harnessing market opportunities (53\%), quality assurance (40\%) and coping against natural disasters (37\% respondent). Organizing and supporting farmers/entrepreneurs for economic scale/commercial and contract seed production, linking to seed markets, infrastructure development, input/s management, strong seed regulation, research back up and farmer's welfare program are needed. Therefore, it is recommended to put in place a priority seed program with clearly defined roles and responsibilities of the stakeholders to ensuring seed self-sufficiency and import substitution in Nepal.
\end{abstract}

\section{Keywords}

Extension, Regulation, Research, Seed, Value chain

\section{Introduction}

Quality seeds of improved and desire varieties are the most important and least expensive agricultural inputs. Availability and accessibility of seeds at right time and location determine the local food productivity, production and food security [1]. Seeds are classified as nucleus, breeder, foundation and certified seeds. The truthful labeled seed is considered as registered seed and $>90 \%$ of the cereal seed comes from informal system in Nepal [2]. There are three different agencies: public, community and private sectors involving on seed sector development in Nepal. Nepal Agriculture Research Council (NARC), Department of Agriculture (DOA) and Agriculture Input Company Ltd (previously National Seed Company Ltd) (AICL) are the public sector led agencies; Farmers Groups (FGs), Cooperatives, Community Based Organizations (CBOs) and their federations are community led; and Seed Entrepreneurs Association Nepal (SEAN), Agrovets, private Seed Companies and seed importers the private led agencies [1]. Among the seed production initiatives, the District Seed Self Sufficiency Program (DISSPRO) and Community Based Seed Production Program (CBSP) 
were started in 2000 and the Community Seed Bank (CSB) in 2010. Beside the public support, HMRP/CIMMYT, IWRMP and USAID were the supporting agencies/projects on these seed initiatives [3]. Annual improved seed production was estimated more than 24,000t, with the seed replaced rate (SRR) of major cereals 15\% (Rice 14.5, Maize 15.3 and Wheat $15.1 \%$ ) in Nepal [4].

The seed value chain differs with commodities, generation and the type of seeds. In a maize value chain in mid hills of Nepal: NARC, DoA, Agrovets, AICL, CIMMYT and cooperatives are the input suppliers. Where, farmers groups/cooperatives, seed companies and government farms are the producers and Seed quality control centers and the regional seed labs regulate the quality. Though, truthful labeling is also in practice. The seed companies, agrovets and importers are the distributors [5].

Organizing farmers into extension and production groups, associations, alliance, federation, etc. and providing technical/advisory support services and linking them to markets is important [6]. Direct support with public funds can be provided to farmer groups or through an intermediary NGO, or the private seed buyer to improve services for contract seed production. General support to the small farm sector through infrastructure (roads, irrigation) or support to farmer organizations; or indirect support through development of rural markets, strengthening local service providers, or passing legislation to improve enforceability of contracts and reduce risk of default by farmers or the private firm are beneficial [7]. The rural seed producers/farmers organization and the seed entrepreneurs can be the good partner for the effective management of public services such as seed research and extension through public-community partnership and implementing participatory approaches [8]. Small farmers in developing countries need engaging in collective action to obtain improved access to agri-support factors [9]. Conventional top down or trickle down agricultural extension approach, block production approach, agriculture assistant and tuki system, training and visit system, farming system and research, the integrated rural development systems and the ATEIP's training and demonstration (TD) farm approach were experienced in the past for the agriculture extension in Nepal [10]. All these efforts were supposed to supporting the seed sector development in Nepal. However, the seed replacement rates (SRR) of major crops until at present are very low [4].

Availability and accessibility of quality seeds of improved and desire varieties at right time, location and quantity are serious problems in Nepal. Available extension and advisory services, research and technical back up, input (source seed, fertilizer/manure, etc), infrastructure, market, subsidy \& credit supports, and capacity building activities, all are insufficient. The capacity of extension/production/entrepreneurs groups, associations, alliance, and federation are very weak. Contract seed production is not stepping ahead and the intermediary NGO, or the private seed buyer are unable to play their role. There are a number of risks associated in every step of seed value chain. All these resulted in lower rate of seed cycling, seed availability and seed replacement rates in Nepal. This is why, it was necessary to study on the impact of agriculture extension and value chain support services for seed sector development in Nepal.

Hence, the research question has been raised weather the agriculture extension and support services are supporting the seed sector development in Nepal? Therefore, this study was designed with the objective to support the seed sector, thereby increasing the seed self sufficiency and SRR in Nepal. However, the specific objectives of the study were:

- $\quad$ to find out the role of agriculture extension and support services for seed sector development in Nepal and

- $\quad$ to suggest the ways to mitigate the limitations of seed sector and recommends policy and strategic options for seed sector development in Nepal.

\section{Methods}

An exploratory review was made to access the status of agriculture extension and support services for the seed sector development in Nepal. Relevant literatures and information were collected from different secondary sources. The articles in journals, books, reports and other relevant printed documents were reviewed that are related to agricultural extension, value chains and seed sector development in Nepal. Web pages were visited.

The list of seed value chain actors in the seed hobs of Nepal (Chitwan, Dolakha and Rupandehi) were collected from SQCC, SEAN, District Seed Entrepreneurs Association and Agriculture Extension Offices. A total of 90 seed value chain actors; the seed producers $(\mathrm{N}=30)$, seed processors $(\mathrm{N}=15)$, input sellers $(\mathrm{N}=15)$ and the seed users $(\mathrm{N}=30)$ were identified. A numbers of consultative interactions were made with the identified value chain actors' individually in each district in the year 2019. A subjective/open question on the limitations of seed sector development and needed demand services to improve it was asked for the interaction. The same question was repeated to input suppliers, seed producers, seed assemblers/processors, traders/retailers and farmers using the seeds. The qualitative information received as their opinions, the problems they were tackling, their suggestions and demand services including the crops cutting issue were noted. All the response and information were compiled, frequency was counted, tabulated, analyzed, the percentage of respondent calculated and presented in the tables and graphs. The manuscript was prepared and the future policy, strategy and programs for strengthening the seed sector development in Nepal were recommended. 


\section{Results}

\subsection{Seed related legislations and guidelines}

A big gap was observed on implementing the seed policies and legislations. Agriculture Prospective Plan (APP), 1995-2015 was the 20 years agriculture vision and long term periodic plan emphasized with the seed sector development in Nepal. With the short comings and the learning of APP the Agriculture Development Strategy (ADS) 2015-2035, with 20 years strategy and 10 years plan has been implementing in Nepal. The Seed Vision, 2013-2025 as the part of ADS has been currently in execution. There has been declared a number of policies, acts and regulations related to seed sector. National Seed Policy 1999, National Agricultural Policy 2004, Agri Business Promotion Policy 2006, Agro-biodiversity Policy 2006 and its revision 2014, National Tee Policy 2000, National Coffee Policy 2003, National Fertilizer Policy 2001 and Irrigation Policy 2003 are some of them. Seed Act 1988 and its first amendment 2008, Pesticide Act 1991, Plant Protection Act 2007, NARC Act 1992 and National Tea and Coffee Development Board Act 1993 and the Seed Regulation 1997/new version 2013, Pesticide Regulation 1994, Irrigation Regulation 2000 and Chemical Fertilizer Control Order 1985 are the legislations related to seed in Nepal. Beside, District Seed Self Sufficiency Program (DISSPRO) and Commercial Seed Production guidelines 2009, Community Seed Bank (CSB) Operating Guidelines 1996, Maize mission guidelines 1995 are the important guide lines. However, a big gap was observed on implementation of these policies and enforcement of the legislation. The supply system is dominated by informal seed system; there lacks well equipped laboratories and qualified manpower, and lacks harmonization of acts and regulations with international agreements. Improvements in these issues are most necessary [1].

\subsection{Agriculture extension approaches and methods}

The role of agriculture extension is mainly linking between agriculture policy, research, education, and training to seed producers, entrepreneurs, farmer's organizations, and the private sector stakeholders [10]. The pluralistic extension approach with pocket package strategy through farmers' group/cooperative focused to small farmers and disadvantaged community and value chain approaches emphasized with public private partnership was in practice in Nepal. Recently, the "Farmers Field School" approach was in advance for seed production and seed post harvest operation. Moreover, the Prime-minister Agriculture Modernization Project has been initiated with pocket, block, zone and super zones as per the pocket package strategy for the agriculture modernization but seed sector has been largely ignored. Thus, at present, a question raised which approach and method/s would be the most effective for seed system/enterprise development in Nepal?

\subsection{Seed extension and service delivery organizations}

With the political transformation in the country, government organizations dealing seed vision and seed regulation have been reformed. The Seed Quality Control Centre (SQCC) under the Ministry of Agriculture and Livestock Development was dealing the seed regulation, research and development in Nepal. Central labs and Seed Testing Labs also were responsible to complement on seed regulation. Plant Quarantine and its net work were responsible to prevent the entry of seed quarantine pests. However, the seed research, variety development and maintenance, breeder and source seed production were the sole responsibility of Nepal Agriculture Research Council (NARC) for open pollinated and hybrid seed research in Nepal. Department of Agriculture together with Federal, Provincial and Local Government, Government farms centers and Agriculture Knowledge Centers have the joint responsibility for seed extension. Agriculture Input Company Ltd (Previously National Seed Company Ltd) (AICL) a government under taken company was responsible for seed supply and seed buffer stocking. A number of INGOs/ NGOs and CBOs were involved on seed sector. Seed Entrepreneurs Association Nepal (SEAN) and its member seed entrepreneurs, private seed companies, seed producer farmer's groups/cooperatives and Agrovets has been serving on seed sector development. However, another genuine question was raised to be answered on "what should be the net work of service delivery organizations with what human resource for seed extension and seed system development in Nepal for the effective delivery of advisory and support services?”

\subsection{Seed programs and support services}

The public sector NARC was focused mainly on seed research and source seed production, DoA on seed extension and advisory services for community seed production (improved) and AICL on seed trading. The private sector (SEAN, Agrovets, Seed Companies) involvement found mainly on seed trading, seed collection, processing, seed import and distributions. Farmers associations/cooperatives and groups has been engaged on improve seed production. However, the seed replacement rate (SRR) of major field crops and vegetables was very low and the seed supply is mostly from informal sectors [1] [4]. DISSPRO, CBSP, CSPP, CSB and some other agricultural projects were the major seed initiatives. Which were supported from CIMMYT/HMRP, KUBK, SSSP, USAID (seed and fertilizer projects), etc. 


\subsubsection{Source seed production}

Nepal Agriculture Research Council (NARC) claimed to be sufficient in breeder and foundation seed production to maintain the seed cycle. NARC produces the breeder and foundation seeds of major cereal, pulses, oilseeds and other crops including rice, maize, wheat, millet, moong, lentil, mustard, jute, cowpea, etc. The production was claimed to be sufficient for producing improved/certified seeds, if follow the seed cycle properly. But in fact, seed growing farmers claimed the supply of the source seed was insufficient to produce sufficient certified/improved seeds and more often inferior quality and unlike of desire varieties in Nepal [1]. Breeder seed production of the major cereals in the year 2017/018 in Nepal was $56.5 \mathrm{t}$ (Rice 2,140 kg, Maize 4,967 kg and wheat 49,366 kg. Where, the source seed production of them in the same year was 957.4t (Rice 441,419 kg, Maize 75,816 kg and wheat 440,194 kg) [4].

\subsubsection{Improved/certified seed production}

Different seed production initiatives for seed system development have been taken in Nepal. DISSPRO initiated in $9^{\text {th }}$ plan 1997-2002 was found most popular, widely adopted and cheapest seed program in Nepal. A larger number of farmer's groups and cooperatives were associated with DISSPRO. There were more than 300 DISSPRO groups producing maize seeds of different OPVs in 2011, more functional in remote hill districts which increased the access of improved seeds to the resource poor farmers [11]. DISSPRO was able to produce $40.4 \%$ of total certified seeds in the country in the year 2011 [1]. Where, the highest volume of seed produced under DISSPRO was rice (53.4\%) followed by wheat (34.36\%) and maize (11.19\%). Other minor crops seed producing under DISSPRO were Moong, Lentil, Rapeseed, Rajma, Cowpea and Barley. Major supports provided from CDD/DoA for DISSPRO were source seed management, technical backstopping, information support, revolving fund, training and small infra-structures like threshing floor, storage, seed processing equipments, seed bins, etc. CBSP was able to produce $6.84 \%$ of the total certified/improved seeds in Nepal. The seed production trend of CBSP also was increasing. CBSP was heavily supported by Hill Maize Research Project (HMRP). This program was able to produced 1500t maize seed each year. CBSP was mainly involved on maize seed production in 20 mid-hill districts. The CBSP activities were variety and technology selection, source seed production and distribution, improved seed production and marketing, contract seed production, capacity building and infrastructures development for seed collection, processing, packaging, storage [1]. Community Seed Banks (CSBs) were mainly involved on rice, maize and wheat seed production in different districts. They were able to produce about $2 \%$ of total improved seeds in Nepal (about 142t/year). Major activities under CSB were creating seed infrastructures for seed collection, processing, packaging, storage and marketing. Provision of seed money and the revolving fund support was the beauty of the CSB. There were a number of CSB supported by DADO/CDD, LiBIRD and OXFAM [1]. Government Seed Company, Corporation and Farms were also involved on improved seed production. Government owned single seed company the Agriculture Input Company Ltd (previously National Seed Company Ltd) (AICL) was able to produce about 25.8\% (4522.422t/year) of the total improved seeds of wheat, rice and lentil in Nepal. Also, the Salt Training Corporation (STC) was producing wheat seeds (610t/year) annually. AICL (previously NSCL) and STC were supporting farmers on source seed, technical supports, facilitating on seed certification and seed purchasing. Government farms (Sundarpur and Chandradangi) were mainly involved on improved seeds production of rice, maize and wheat (115.452 t/year). National Industrial Crop Development Program (NICDP) was supporting on improve seed production of jute and mustard (3.4 t/year) [1]. Private registered seed companies were able to produce 23.85\% ( $\mathrm{N}=17$ ) improved seeds of wheat, rice and lentil in Nepal. They were supporting farmers on source seed, technical supports, facilitating on seed certification and seed purchasing [1]. The donor supported projects mainly SSSP, IWRMP, KUBK, PACT, Seed and fertilizer project, etc were also involved on commercial seed production and marketing/distribution in Nepal. Capacity building, farmers training, source seed management, seed infrastructures development (collection, processing, packaging, storage and marketing) and subsidy support to the farmers and entrepreneurs were the major activities performed by these projects [1]. Among the total certified seeds produced in Nepal, highest volume was of wheat (50.01\%) followed by rice $37.9 \%$, maize $10.42 \%$ and lentil $1.16 \%$. Negligible seeds were produced in rest other crops [1]. However, integration of all these seed production and marketing initiatives has been demanded by the stakeholders to avoid duplication and overlapping and proper utilization of the resources that gives synergies on seed system development in Nepal.

\subsection{Seed value chain and demand services}

A number of support services were demanded by the respondents in a seed value chain. The qualitative information received from the seed producers $(\mathrm{N}=30)$, processors $(\mathrm{N}=15)$, sellers $(\mathrm{N}=15)$ and users $(\mathrm{N}=30)$ from Chitwan, Dolakha and Rupandehi (Total $\mathrm{N}=90$ ) in the year 2019 found that the availability of quality inputs was the most demanded service (77\%), followed by strong research backup (72\%), post harvest loss reduction (70\%) and skill development training (69\%). There were number of services demanded by different value chain actors in a seed value chain in Chitwan, Dolakha and Rupandehi (Figure 1). They were alike the findings of Gurung et al. [11].

However, the frequency of the demand services were different on the various steps of the seed value chain (input 
supply, seed production, assemblage, processing, trading, retailing and seed use) including the cross cutting issues (Tables 1, 2, 3, 4, 5, 6 \& 7), which are explained below:

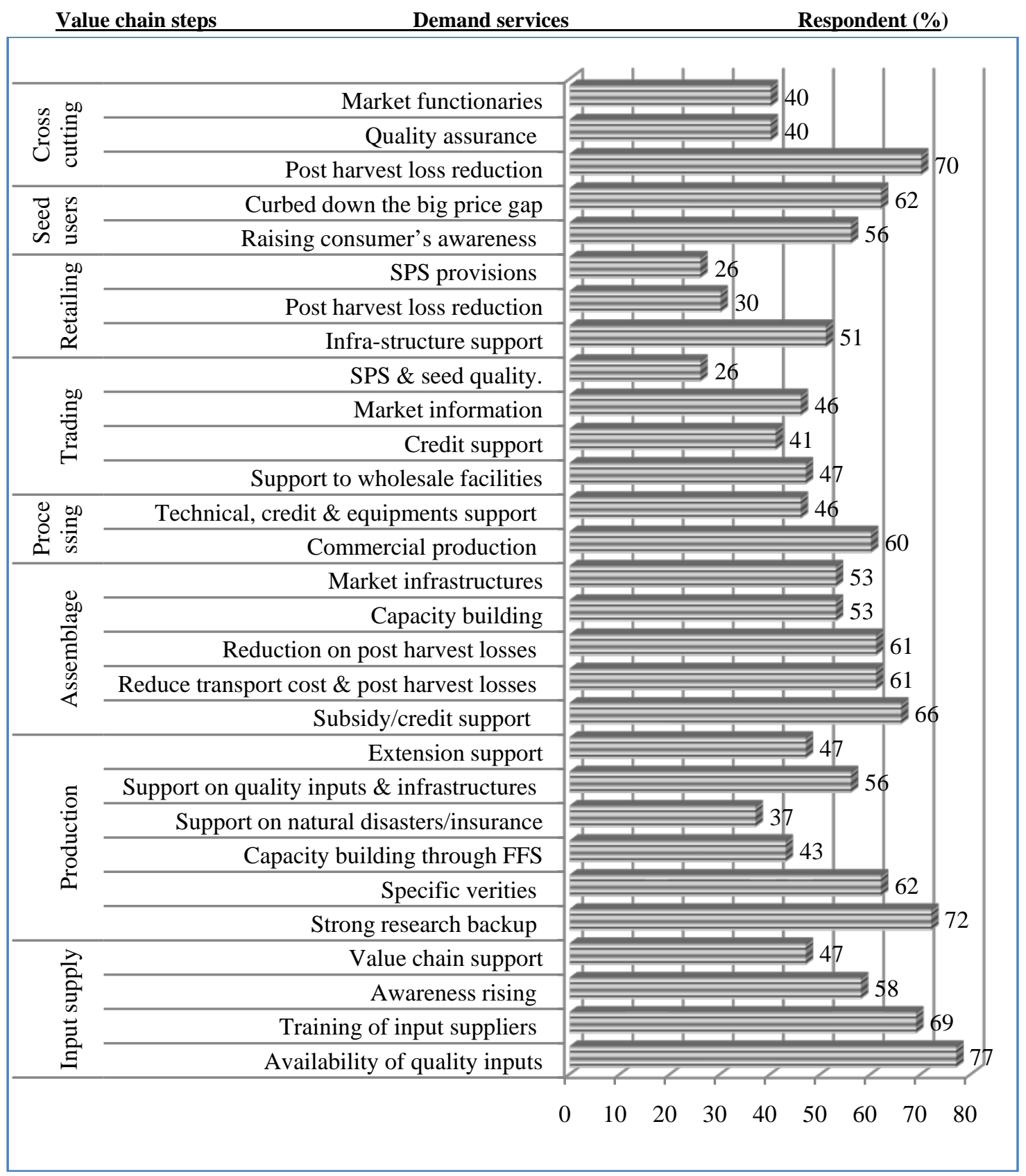

Figure 1. Seed value chain demand services (respondent \%, N=90), Chitwan, Dolakha and Rupandehi (2019).

\section{a. Input Supply}

Sufficient and timely availability of quality inputs like source seed, fertilizer and manure was the most demanded service for the source and improved seed production ( $\mathrm{N}=69)$. It was most demanded by the seed users (100\%) followed by seed producers $(90 \%)$ and seed sellers (80\% respondent). Training and mobilization of seed groups for quality seed production/regulation and enabling seed quality control system was demanded by $69 \%$ respondent $(\mathrm{N}=62)$. All most all seed sellers (100\%) followed by seed users (87\%) and seed producers (53\% respondent) demanded this. Need of raising awareness among farmers ( $58 \%, \mathrm{~N}=52)$ on quality seed $(\mathrm{N}=62)$ through demonstration, farmers' workshop, awareness campaigning, farmer's field days, etc was also demanded. Support value chain in establishing improved/quality seed (seed village/CBSP/DISSPRO/CSB) and seed flow systems to raise the SRR (N=52) were also demanded by all the groups of the respondent in a seed value chain (Figure 2). 


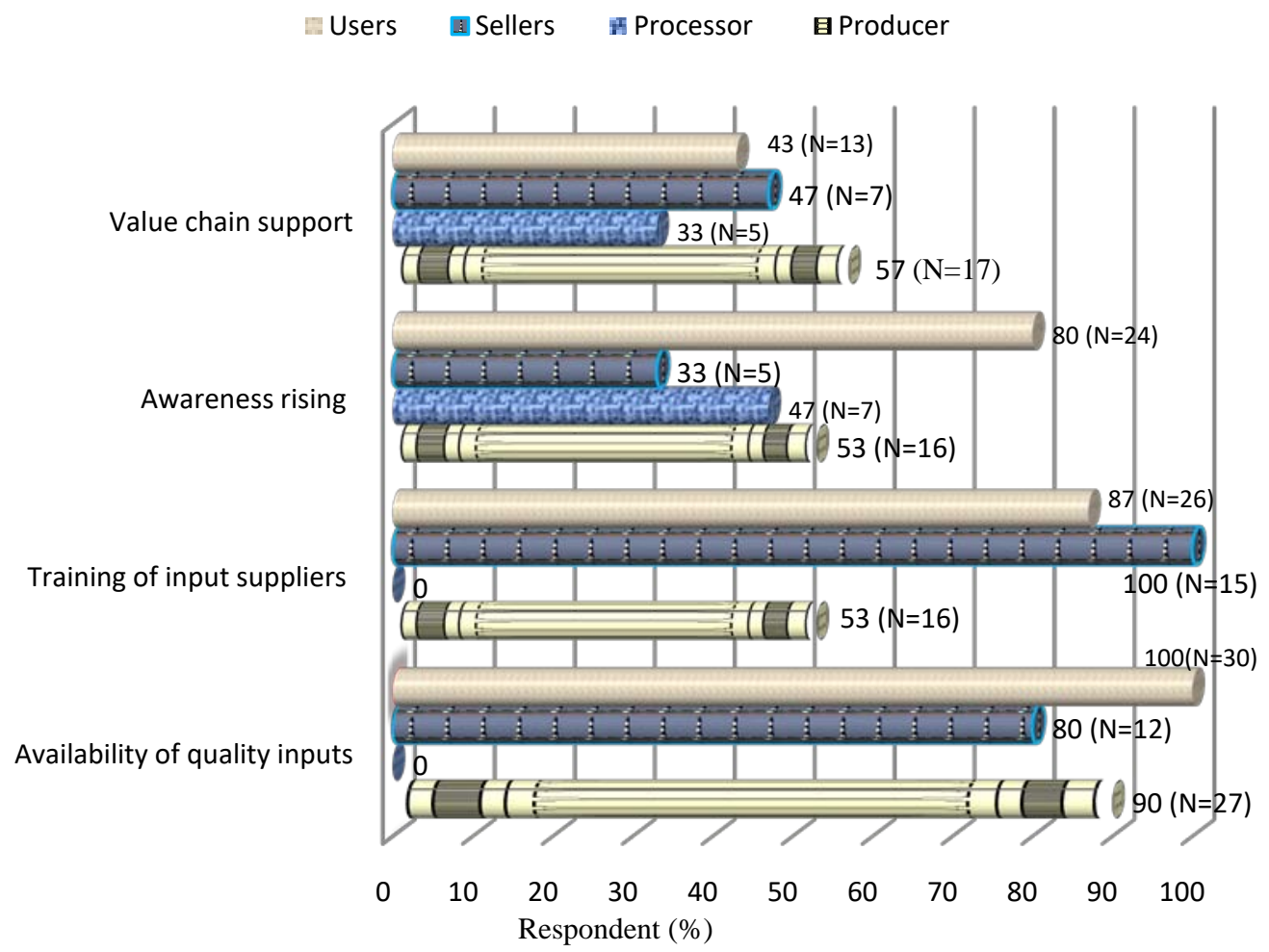

Figure 2. Demand services on input supply, Chitwan, Dolakha and Rupandehi (2019).

\section{b. Production}

A strong research backup was demanded that includes developing improved technological package $(\mathrm{N}=65)$ to hand over for farmers through the extension network. Need higher yielding, location specific varieties resistant to diseases, insects, weeds and heat/moisture stresses $(\mathrm{N}=56)$ for different domains. It is strongly demanded by more than $90 \%$ seed users and the seed producers. Need to have low cost technology to reduce the production cost and conservation of local germ plasma $(\mathrm{N}=65)$. Another important service demanded by all the groups of the value chain actors, was the improved crop production and capacity building that includes: facilitating seed growers in the identification and adoption of varieties to fully harness the market opportunities through participatory variety selection (PVS), quality production with national and international standards, demand based production with pre-prepared production plan, crop production with good agricultural practices (GAP), planting time \& methods, irrigation, IPM, soil (fertilizers/manure) management and seed harvesting time with farmers research on agronomic practices in a FFS ( $N=39)$ with crop compensation from natural disasters and crop insurance $(\mathrm{N}=33)$. The high production cost was a big headache for the farmers. Reduction of seed production cost needs to assist farmers in reducing their cost of production and achieve competitive and comparative advantage over the import. More than $50 \%$ of the respondent from seed producers and a considerable proportion from all other groups demanded these services. Adoption of appropriate location specific suitable variety and availability of cheaper and quality inputs (seeds, fertilizers) and adoption of appropriate improved production management practices including farm mechanization were also demanded $(\mathrm{N}=50)$. Development of rural infrastructure including farm to market link roads, collection points, storage/super bags, grading, processing, packing facilities with equipments/infra structures, etc were also demanded. Provision of sufficient number of grass root extension workers (public, community, private) $(\mathrm{N}=42)$ with ICT for wider diffusion of technologies and practices were also on high demand (see Table 1 , Figure 1).

\section{c. Assemblage}

All the seed processors and about $50 \%$ of the producers, sellers and the users raised the problems of lacking/insufficient collection centers, the packaging materials and methods on seed assemblage. They demanded subsidy support from the government for this $(\mathrm{N}=59)$. More than $80 \%$ of the seed sellers and processors and considerable numbers of seed producers and users demanded on reduction of higher transportation cost, need of sufficient credit support on assemblage, reduction of post harvest losses, i.e., supporting threshing floors, equipments and super-bags with storage facilities $(\mathrm{N}=55)$ (see Table 2, Figure 1$)$. 
Table 1. Demand services on production in a seed value chain, Chitwan, Dolakha and Rupandehi, 2019

\begin{tabular}{|c|c|c|c|c|c|c|}
\hline \multirow[b]{2}{*}{ SN } & \multirow[b]{2}{*}{ Service demanded } & \multicolumn{5}{|c|}{ Respondent (\%) } \\
\hline & & $\begin{array}{l}\text { Producer } \\
(\mathbf{N}=30)\end{array}$ & $\begin{array}{l}\text { Processor } \\
(\mathrm{N}=15)\end{array}$ & $\begin{array}{l}\text { Sellers } \\
(\mathbf{N}=15)\end{array}$ & $\begin{array}{l}\text { Users } \\
(\mathrm{N}=\mathbf{3 0})\end{array}$ & $\begin{array}{l}\text { Total } \\
(\mathbf{N}=\mathbf{9 0})\end{array}$ \\
\hline 1 & $\begin{array}{l}\text { A strong research backup for developing low cost, im- } \\
\text { proved technological package and conservation of local } \\
\text { germ plasma. }\end{array}$ & $90(27)$ & $47(7)$ & $53(8)$ & $77(23)$ & $72(65)$ \\
\hline 2 & $\begin{array}{l}\text { Need higher yielding, location specific verities for differ- } \\
\text { ent domains, resistant to diseases, insects, weeds and } \\
\text { heat/moisture stresses. }\end{array}$ & $30(15)$ & $33(5)$ & $53(8)$ & $93(28)$ & $62(56)$ \\
\hline 3 & $\begin{array}{c}\text { Capacity building through agriculture extension and } \\
\text { training on seed production, variety selection, production } \\
\text { planning, seed quality assurance, GAP and seed marketing } \\
\text { in a FFS }\end{array}$ & 43(13) & 20(3) & $33(5)$ & $60(18)$ & $43(39)$ \\
\hline 4 & $\begin{array}{l}\text { Farmer's welfare, with crop compensation from natural } \\
\text { disasters and crop insurance. }\end{array}$ & $50(15)$ & $13(2)$ & $20(3)$ & $43(13)$ & 37(33) \\
\hline 5 & $\begin{array}{l}\text { Support on quality seeds, fertilizers, farm machineries and } \\
\text { farm infrastructures }\end{array}$ & $60(18)$ & $60(9)$ & $27(4)$ & 63(19) & $56(50)$ \\
\hline 6 & $\begin{array}{l}\text { Provision of sufficient grass root extension workers (pub- } \\
\text { lic, community, private) for wider diffusion of technolo- } \\
\text { gies and practices }\end{array}$ & $30(9)$ & $53(8)$ & $53(8)$ & $57(17)$ & $47(42)$ \\
\hline
\end{tabular}

Note: Figures in parenthesis are the respondent number (frequency). The number and the percentage exceeded because of multiple responses.

Table 2. Demand services on assemblage in a seed value chain, Chitwan, Dolakha and Rupandehi, 2019

\begin{tabular}{|c|c|c|c|c|c|c|}
\hline \multirow[b]{2}{*}{ SN } & \multirow[b]{2}{*}{ Service demanded } & \multicolumn{5}{|c|}{ Respondent (\%) } \\
\hline & & $\begin{array}{c}\text { Producer } \\
(\mathrm{N}=30)\end{array}$ & $\begin{array}{c}\text { Processor } \\
(\mathrm{N}=15)\end{array}$ & $\begin{array}{l}\text { Sellers } \\
(\mathrm{N}=15)\end{array}$ & $\begin{array}{c}\text { Users } \\
(\mathrm{N}=\mathbf{3 0})\end{array}$ & $\begin{array}{r}\text { Total } \\
(\mathrm{N}=90)\end{array}$ \\
\hline 1 & $\begin{array}{l}\text { Subsidy/credit support on assemblage like collection cen- } \\
\text { ters, packaging materials and methods they are either } \\
\text { lacking or insufficient. }\end{array}$ & $57(17)$ & $100(15)$ & $87(13)$ & $47(14)$ & $66(59)$ \\
\hline 2 & $\begin{array}{l}\text { Reduction on higher transportation cost, reduction on post } \\
\text { harvest losses i.e. supporting threshing floors, equipments, } \\
\text { super-bags \& storage facilities. }\end{array}$ & $50(15)$ & $93(14)$ & $80(12)$ & $47(14)$ & $61(55)$ \\
\hline 3 & $\begin{array}{l}\text { Enhancing capacity of collectors and traders in post harv- } \\
\text { est management practices for curing, grading and packag- } \\
\text { ing facilities in the commercial production areas with } \\
\text { public, community and private investments for market } \\
\text { infrastructures. }\end{array}$ & $43(13)$ & $100(15)$ & $60(9)$ & $37(11)$ & $53(48)$ \\
\hline
\end{tabular}

Note: Figures in parenthesis are the respondent number (frequency). The number and the percentage exceeded because of multiple responses.

Enhancing capacity of collectors (100\%) and traders (60\%) in post harvest management practices for curing, grading and packaging facilities in the commercial production areas with public, community and private sector investments and developing market infrastructures ( $\mathrm{N}=48$ ) also were demanded (see Table 2, Figure 1).

\section{d. Processing}

About $60 \%$ of the respondents from all of the groups raised the question of the small production units with poor investment capacity, resulting small marketable volume with susceptible to production and marketing problems $(\mathrm{N}=54)$, which needs to be solved. All the seed processors (100\%), about $67 \%$ of seed sellers, a considerable number of seed producers and the end users demanded technical, financial/credit and equipments support for seed industries for processing and packing ( $\mathrm{N}=41)$ (Table 3, Figure 1$)$. 
Table 3. Demand services on processing in a seed value chain, Chitwan, Dolakha and Rupandehi, 2019

\begin{tabular}{|c|c|c|c|c|c|c|}
\hline \multirow[b]{2}{*}{ SN } & \multirow[b]{2}{*}{ Service demanded } & \multicolumn{5}{|c|}{ Respondent (\%) } \\
\hline & & $\begin{array}{c}\text { Producer } \\
(\mathrm{N}=30)\end{array}$ & $\begin{array}{l}\text { Processor } \\
(\mathrm{N}=15)\end{array}$ & $\begin{array}{l}\text { Sellers } \\
(\mathrm{N}=15)\end{array}$ & $\begin{array}{c}\text { Users } \\
(\mathrm{N}=\mathbf{3 0})\end{array}$ & $\begin{array}{l}\text { Total } \\
(\mathrm{N}=90)\end{array}$ \\
\hline 1 & $\begin{array}{l}\text { Small production units with poor investment resulting } \\
\text { small marketable volume with susceptible to production } \\
\text { and marketing problems. }\end{array}$ & $70(21)$ & $87(13)$ & $53(8)$ & $40(12)$ & $60(54)$ \\
\hline 2 & $\begin{array}{l}\text { Technical, financial/credit \&equipments support for } \\
\text { agro-industries for processing \& packing is lacking. }\end{array}$ & $30(9)$ & 100(15) & $67(10)$ & $23(7)$ & $46(41)$ \\
\hline
\end{tabular}

Note: Figures in parenthesis are the respondent number (frequency). The number and the percentage exceeded because of multiple responses.

\section{e. Trading}

A distinct number of producer, processor, users and all most all sellers indicated that there are lacking the wholesale facilities and there lacks the credit support on seed trading. Insufficient wholesale facilities ( $\mathrm{N}=42)$, lack/insufficient credit support $(\mathrm{N}=37)$, poor market information $(\mathrm{N}=41)$ and the issue of sanitary and phyto-sanitary (SPS) measures needs to be improved $(\mathrm{N}=23)$. All the seed sellers $(100 \%)$, more than two third of the seed processors, and a considerable numbers of seed producers, raised these questions (Table 4, Figure 1).

Table 4. Demand services on trading in a seed value chain, Chitwan, Dolakha and Rupandehi, 2019

\begin{tabular}{|c|c|c|c|c|c|c|}
\hline \multirow[b]{2}{*}{ SN } & \multirow[b]{2}{*}{ Service demanded } & \multicolumn{5}{|c|}{ Respondent (\%) } \\
\hline & & $\begin{array}{c}\text { Producer } \\
(\mathrm{N}=30)\end{array}$ & $\begin{array}{c}\text { Processor } \\
(\mathrm{N}=15)\end{array}$ & $\begin{array}{l}\text { Sellers } \\
(N=15)\end{array}$ & $\begin{array}{c}\text { Users } \\
(\mathrm{N}=30)\end{array}$ & $\begin{array}{c}\text { Total } \\
(\mathrm{N}=90)\end{array}$ \\
\hline 1 & Insufficient wholesale facilities & $50(15)$ & $60(9)$ & $100(15)$ & $10(3)$ & $47(42)$ \\
\hline 2 & Lack/insufficient credit support & $33(10)$ & $80(12)$ & $100(15)$ & $0(0)$ & $41(37)$ \\
\hline 3 & Poor market information & $17(5)$ & $80(12)$ & $60(9)$ & $5(15)$ & $46(41)$ \\
\hline 4 & $\begin{array}{l}\text { Issue of sanitary \& phyto-sanitary (SPS) provisions need } \\
\text { to be resolved to maintain the seed quality. }\end{array}$ & $7(2)$ & $47(7)$ & $60(9)$ & $17(5)$ & $26(23)$ \\
\hline
\end{tabular}

Note: Figures in parenthesis are the respondent number (frequency). The number and the percentage exceeded because of multiple responses.

\section{f. Retailing}

There were a number of problems on seed retailing. Lack of retailing shops especially the retailing infra-structure $(\mathrm{N}=46)$, insect infestation and rat damage in store $(\mathrm{N}=27)$ and issue of sanitary provisions $(\mathrm{N}=23)$ need to be resolved to maintain the seed quality. Majority of the seed retailers, traders, processors and a considerable number of seed producers raised these issues (Table 5, Figure 1).

Table 5. Demand services on retailing in a seed value chain, Chitwan, Dolakha and Rupandehi, 2019

\begin{tabular}{|c|c|c|c|c|c|c|}
\hline \multirow[b]{2}{*}{ SN } & \multirow[b]{2}{*}{ Service demanded } & \multicolumn{5}{|c|}{ Respondent (\%) } \\
\hline & & $\begin{array}{l}\text { Producer } \\
(\mathrm{N}=30)\end{array}$ & $\begin{array}{l}\text { Processor } \\
(\mathrm{N}=15)\end{array}$ & $\begin{array}{l}\text { Sellers } \\
(\mathrm{N}=15)\end{array}$ & $\begin{array}{c}\text { Users } \\
(\mathrm{N}=30)\end{array}$ & $\begin{array}{l}\text { Total } \\
(\mathrm{N}=90)\end{array}$ \\
\hline 1 & Lack of retailing shops (infra-structure) & $43(13)$ & $47(7)$ & $87(13)$ & $43(13)$ & $51(46)$ \\
\hline 2 & Insect infestation and rat damage in store & $17(5)$ & $73(11)$ & 73(11) & $0(0)$ & $30(27)$ \\
\hline 3 & $\begin{array}{c}\text { Issue of sanitary and phyto-sanitary (SPS) provisions to be } \\
\text { resolved to maintain the quality. }\end{array}$ & $7(2)$ & $47(7)$ & $60(9)$ & $17(5)$ & 26(23) \\
\hline
\end{tabular}

Note: Figures in parenthesis are the respondent number (frequency). The number and the percentage exceeded because of multiple responses.

\section{g. Consumption}

Majority (87\%) of the seed sellers, seed processors (73\%), seed users (63\%) and a good number of seed producers demanded raising consumer's awareness on seed label, seed quality, seed sanitary and phyto-sanitary standards and pesticide residue $(\mathrm{N}=50)$. Majority $(93 \%)$ of the seed producers and seed users $(70 \%)$ demanded to curb down the big price gap between farm gates to seed retailing ( $\mathrm{N}=56)$ (Table 6, Figure 1). 
Table 6. Demand services on seed use in a seed value chain, Chitwan, Dolakha and Rupandehi, 2019

\begin{tabular}{|c|c|c|c|c|c|c|}
\hline \multirow[b]{2}{*}{ SN } & \multirow[b]{2}{*}{ Service demanded } & \multicolumn{5}{|c|}{ Respondent (\%) } \\
\hline & & $\begin{array}{l}\text { Producer } \\
(\mathrm{N}=30)\end{array}$ & $\begin{array}{l}\text { Processor } \\
(\mathrm{N}=15)\end{array}$ & $\begin{array}{l}\text { Sellers } \\
(\mathrm{N}=15)\end{array}$ & $\begin{array}{l}\text { Users } \\
(\mathrm{N}=30)\end{array}$ & $\begin{array}{l}\text { Total } \\
(\mathbf{N}=90)\end{array}$ \\
\hline 1 & $\begin{array}{l}\text { Raising consumer's awareness on seed label, seed quality, } \\
\text { seed sanitary/phyto-sanitary standards and pesticide resi- } \\
\text { due }\end{array}$ & 23(7) & $73(11)$ & $87(13)$ & 63(19) & $56(50)$ \\
\hline 2 & $\begin{array}{l}\text { Need to be curbed down the big price gap between farm } \\
\text { gates to retailing }\end{array}$ & $93(28)$ & $47(7)$ & $0(0)$ & $70(21)$ & $62(56)$ \\
\hline
\end{tabular}

Note: Figures in parenthesis are the respondent number (frequency). The number and the percentage exceeded because of multiple responses.

\section{h. Cross cutting issues}

More than two third of the respondent (87\% seed processors, $80 \%$ seed traders, $70 \%$ producers and $57 \%$ end users) asked to reduce the post harvest losses due to pest and diseases in each steep of value chain ( $\mathrm{N}=63$ ) which can help on maintaining the seed quality. There was an immediate need of maintaining strong institutional set up (groups/cooperatives) of value chain actors, producers and market intermediaries for adoption of quality control mechanism and market functionaries (40\% respondent) (Table 7, Figure 1).

Table 7. Cross cutting demand services in a seed value chain, Chitwan, Dolakha and Rupandehi, 2019

\begin{tabular}{|c|c|c|c|c|c|c|}
\hline \multirow[b]{2}{*}{ SN } & \multirow[b]{2}{*}{ Service demanded } & \multicolumn{5}{|c|}{ Respondent (\%) } \\
\hline & & $\begin{array}{c}\text { Producer } \\
(\mathrm{N}=\mathbf{3 0})\end{array}$ & $\begin{array}{c}\text { Processor } \\
(\mathbf{N}=15)\end{array}$ & $\begin{array}{l}\text { Sellers } \\
(N=15)\end{array}$ & $\begin{array}{c}\text { Users } \\
(\mathrm{N}=30)\end{array}$ & $\begin{array}{c}\text { Total } \\
(\mathrm{N}=90)\end{array}$ \\
\hline 1 & $\begin{array}{l}\text { Need to reduce the post harvest losses due to pest and } \\
\text { diseases in each steep of value chain for maintaining the } \\
\text { seed quality. }\end{array}$ & $70(21)$ & 87(13) & $80(12)$ & $57(17)$ & $70(63)$ \\
\hline 2 & $\begin{array}{l}\text { Maintain strong institution (groups/cooperatives) of value } \\
\text { chain actors: producers and market intermediaries for } \\
\text { adoption of quality control mechanism \& market functio- } \\
\text { naries }\end{array}$ & $43(13)$ & $33(5)$ & $47(7)$ & $37(11)$ & $40(36)$ \\
\hline
\end{tabular}

Note: Figures in parenthesis are the respondent number (frequency). The number and the percentage exceeded because of multiple responses.

\section{Discussion}

Seed related legislations and guidelines in Nepal are more or less similar to her neighboring country India. India owns Seed Act (1966), Seed Rules (1968), Seed (Control) Order (1983), Seeds Regulation, 1989, National Seed Policy (2002) and Seed Bill (2004), etc [12]. The Seed Vision, 2013-2025 as the part of ADS is one of the most important strategy and plan for seed sector development in Nepal. Moreover, the National Seed Policy 1999, Seed Act 1988 and its first amendment 2008, and the Seed Regulation 1997/new version 2013 are most important legislation. In addition, some of the guidelines are also followed. However, a big gap was observed on implementation of these policies and the legislation [1]. The pluralistic extension approaches with pocket package strategy through farmers' group/cooperative emphasized with public private partnership are in practice in Nepal [10]. Chinese rural advisory service (RAS) is reaching millions of farmers in a poverty oriented, ecological, and sustainable way throughout the country [13]. However, the public extension coverage is very poor $[14,15]$. In Nepal, the Seed Quality Control Centre (SQCC), Central labs and the Seed Testing Labs with their poor net work is responsible for seed regulation with weak service delivery mechanism. NARC is responsible for seed research, variety development and maintenance, breeder and source seed production but the work until this time is insufficient. Private and community organizations are also not strong enough technically and financially. Agriculture extension service delivery is also not strong enough. That is why, the seed replacement rate is very low in Nepal [1,4]. Quality seeds of improved and desire varieties are the most important and least expensive agricultural inputs [1]. However, farmers in South Asia are using mostly the farm saved seeds which are in general inferior to improved seeds. The seed replacement rate in India for the field crops is only $30 \%$ and majority seeds use are farm saved seeds (70\%) [16]. The situation is still poor in Nepal, with the SRR of major cereals $15 \%$ (Rice 14.5, Maize 15.3 and Wheat 15.1\%) in Nepal [4].

NARC, DoA, Agrovets, AICL, NGO/INGOs and cooperatives are the major input suppliers in seed production and the seed companies, agrovets and importers are the seed distributors in Nepal [5]. However, sufficient and timely avail- 
ability of quality inputs like source seed, fertilizer and manure was the most demanded service for the seed users $(100 \%)$, seed producers (90\%) and seed sellers $(80 \%)$. Training for quality seed and enabling seed quality control system was demanded by all most all seed sellers (100\%), seed users (87\%) and seed producers (53\%). Need of awareness raising on quality seed use among farmers (58\%) through demonstration, farmers' workshop, awareness campaigning, farmer's field days, etc was also demanded. Where, farmers groups/cooperatives, seed companies and government farms are the seed producers [5]. Seed quality control centers and the regional seed labs regulate the seed in every steps of value chain. Though, truthful labeling is also in practice. At production level, the need of a strong seed research $(90 \%$ respondents), developing low cost technology, and conservation of local germ plasma ( $\mathrm{N}=65)$ were demanded. Adoption of seed FFS $(\mathrm{N}=39)$, seed crop insurance against natural disasters $(\mathrm{N}=33)$, support of location specific suitable variety and availability of cheaper and quality inputs (seeds, fertilizers), support on farm mechanization and rural/farm infra structures $(\mathrm{N}=50)$ were also demanded. Provision of sufficient number of grass root extension workers (public, community, private) $(\mathrm{N}=42)$ with ICT for wider diffusion of technologies and practices were also on high demand. Strengthening the DISSPRO, CBSP, CSPP and CSB seed initiatives is necessary. Establishing the seed village/CBSP/DISSPRO/CSB is needed. Integration of all these seed production and marketing initiatives has been demanded by the stakeholders to avoid duplication and overlapping and proper utilization of the resources that gives synergies on seed system development in Nepal. On seed assemblage, all the seed processors and about $50 \%$ of the producers, sellers and the users raised the problems of lacking/insufficient collection centers, the packaging materials and methods on seed assemblage. Sufficient credit support on assemblage, infrastructures, threshing floors, equipments and super-bags with storage facilities $(\mathrm{N}=55)$ were demanded. At the processing level, small marketable volume of seed and poor investment capacity are the major constraints $(\mathrm{N}=54)$. All the seed processors $(100 \%)$, about $67 \%$ of seed sellers, a considerable number of seed producers and the end users demanded technical, financial/credit and equipments support for seed industries for processing and packing $(\mathrm{N}=41)$. The major stakeholders on seed trading in Nepal are the seed companies, agrovets and importers [5]. The wholesale facilities are lacking $(\mathrm{N}=42)$ with insufficient credit support $(\mathrm{N}=37)$ on seed trading. Market information is very poor $(\mathrm{N}=41)$ and the issue of sanitary and phyto-sanitary (SPS) measures needs to be improved ( $\mathrm{N}=23)$. Retailing infra-structure are also lacking $(\mathrm{N}=46)$, insect infestation and rat damage in seed storage is common $(\mathrm{N}=27)$ and issue of sanitary provisions $(\mathrm{N}=23)$ need to be resolved to maintain the seed quality. Raising consumer's awareness on seed label, seed quality, seed sanitary and phyto-sanitary standards and pesticide residue are important factors $(\mathrm{N}=50)$. Majority of the seed producers $(93 \%)$ and seed users $(70 \%)$ demanded to curb down the big price gap between farm gates to seed retailing $(\mathrm{N}=56)$ at the seed consumption level. More than two third of the respondent (87\% seed processors, $80 \%$ seed traders, $70 \%$ producers and $57 \%$ end users) asked to reduce the post harvest seed losses. Need of maintaining strong institutional set up of value chain actors has been strongly pointed out (40\%). All these issues tally with the findings of Gurung et al. 2011 [11].

\section{Conclusion}

The key findings of the study indicated slow pace of seed sector development with insufficient infrastructures, extension and value chain support services in Nepal. A set of seed legislations are there, pluralistic agriculture extension system coupled with a number of seed production initiatives are in place, government, non-government, private and community organizations are involved on it. However, the seed replacement rate was very low and the value chain actors are demanding a number of support services that includes regulation for quality inputs, input supply/management, infrastructure development, research back up, market oriented extension and advisory services, timely availability of market information, capacity building, curbing down the big price gap, disaster and post harvest risk/loss reduction, awareness creation, farmers welfare scheme and output based technical and credit supports on seed production, assemblage, trading and seed use.

There were a lot of challenges on the seed system development in Nepal. There were very limited varietal options especially for the remote areas (as maize in Karnali). Even in the accessible areas, the extension education and support services on each step of value chain were insufficient. Seed quality control mechanism was very weak. The seed cycle was not strongly followed. Miss use of seeds, poor technical knowhow, and low seed holding capacity of the rural poor farmers with limited storage and processing facilities has been prevailed. Private sector involvement was very limited. Investment in seed sector was very low. Seed marketing network was fragile. The seed production initiatives were poorly funded. All these constraints were making inconsistent and insufficient seed supply enabling to maintain the seed cycle resulting poor seed replacement rate (SRR) in Nepal.

Based on the finding following recommendation are made for developing market oriented profitable and competitive seed business, for increasing the farm income and rural employment in Nepal:

- Strengthen the regulation for quality inputs like source seed, fertilizer etc. Awareness rising on quality inputs and training of the input suppliers are recommended

- Strong research backup on quality seed production, supply of sufficient source seed of demanded verities, 
capacity building of seed producer through FFS, disaster risk reduction and seed insurance, support on quality inputs, infrastructures and extension/advisory services are recommended.

- Subsidy/credit supports on seed assemblage, especially for reduction of transport cost, minimize post harvest losses and developments of market infrastructure are needed.

- Commercial seed production and supply for seed processing is needed. It needs technical, credit and equipments support for seed processing.

- Government should have a role for market development and linking farmers to markets to have the profitable and competitive seed enterprises and transferring the demand into production.

- $\quad$ Seed trading needs support on wholesale and retailing facilities. Credit support and market information and post harvest loss reduction are important on seed trading. Capacity development to meet SPS and seed quality standard is necessary.

- $\quad$ Raising consumer's awareness and curbing down the big price gaps are important for the seed users.

- It is recommended to have the priority seed programs of the governments. Local and provincial government should emphasized on seed self sufficiency and federal government on commercial/large scale seed production and hybrid seed production.

- Reforming the seed extension and research organizations, linking small producer seed farmers with contract seed production and on boarding the local market oriented advisory service providers in a seed value chain is recommended.

- Organizing the seed farmers/entrepreneurs for economies of scale with commercial and contract seed production, seed collection, processing, packaging and distribution is needed.

- The advisory and support services demanded by the seed value chain actors in different steps should be justified.

- $\quad$ All the activities should be carried out in the seed value chain, with a clearly defined role and responsibilities of the stakeholders for seed self sufficiency and import substitution in Nepal.

\section{Acknowledgements}

This research/study did not receive any specific grant from funding agencies in the public, commercial, or not-for-profit sectors. I express my sincere thanks to my wife Laxmi Kumari Uprety on helping me on field level interaction/visit and my elder son Sumit for editing the manuscript.

\section{References}

[1] Pokhrel, S. (2012). Role of DISSPRO and CBSP on current seed supply situation in Nepal. Journal of Agriculture and Environment, 13: 53-59.

[2] Paudel, M. N., Pokhrel, S., Gadal, N., Ferrara, G. O., KC, D., Joshi, P., and Humagain, R. (2013). An overview of different seed production initiatives in Nepal. Agronomy Journal of Nepal (Agron JN), 3: 1-10.

[3] CDD (Crop Development Directorate). (2011). Annual Report, 2068/069.

[4] SQCC (Seed Quality Control Centre). (2018). National Seed Balance Sheet-2074/075. http://sqcc.gov.np/images/category/ National-Seed-Balance-Sheet-2074-75.pdf.

[5] CDD (Crop Development Directorate). (2012). Annual Report, 2069/070.

[6] Swanson, B. E. (2006). The changing role of agricultural extension in a global economy. J. Int. Agric. Edu. Ext., 13(3): 5-17.

[7] Swanson, B. E. (2005). Extension strategies for poverty alleviation-lessons from China and India. J. Agric. Edu. Ext., 12(4): 285-299.

[8] Rivera, W. M. (2003). Agricultural extension, rural development and the food security challenge. Rome: FAO, Research, Extension and Training Division.

[9] Sulaiman, R. V. and Van den Ban, A. W. (2000). Agricultural extension in India: the next step. NCAP Policy Brief. New Delhi: ICAR.

[10] Subedi, M. and Kaplowitz, M. (2016). What every extension worker should know-core competency handbook. USAID, Michigan State University, and MEAS. P. 184.

[11] Gurung, D. B., Dilli Bahadur, K. C., Ferrara, G. O., Gadal, N., Pokhrel, S., Bhandari, D. R., Koirala, K. B., Bhandari, B. R., and Tripathi, M. (2011). Maize value chains in Nepal. https://www.researchgate.net/publication/325451135_ Or_701_Maize_value_chains_in_Nepal

[12] Santhy, V., Vijaya Kumari, P. R., Vishwanathan, A., and Deshmukh, R. K. (2019). Legislations for Seed Quality Regulation in India. https://www.cicr.org.in/pdf/legislation_seed_quality.pdf.

[13] Kaegi, S. (2015). Reaching the Millions. https://www.shareweb.ch/site/Learning-and-Networking/sdc_km_tools/Documents/ 
RAS\%20Capitalization/ras_capex_china.pdf.

[14] Pokhrel, S. (2020). Food availability and consumption in relation to developing strategies for sustained production and supply in Nepal. Journal of Agriculture and Forestry University, 4: 13-28.

[15] Pokhrel, S. (2020). Impact of Covid-19 Lockdown on Agriculture and Developing Strategies Against it for Sustained Food Production and Supply: Special Focus to Nepal. Journal of Environment Sciences.

[16] Singh, R. P., Agarwal, D. K., Rajendra Prasad, S., Sripathy, K. V., and Jeevan Kumar, S. P. (2008). Seed and Varietal Adoption in Era of Climate Change. https://krishi.icar.gov.in/jspui/bitstream/123456789/11967/1/Book\%201.pdf. 